\title{
Teachers' Roles in Evidence-based Educational Reform in China
}

\author{
Alan C.K. Cheung \\ Department Chairperson \& Professor, Department of Educational Administration and \\ Policy, The Chinese University of Hong Kong, Hong Kong 999077, China.
}

"Education reform has as its main purpose to make sure that the education delivered is of quality."

-Enrique Pena Nieto

$\mathrm{T}$ HE evidence-based educational reform was initiated in the field of medicine and now has become a cutting-edge reform wave in the world. As a new pattern of educational reform, it aims to optimize educational decisionmaking and practice and promote the improvement of education quality, using scientific research evidence. Contrary to experience-based traditional education practice, evidence-based education emphasizes scientific support and data collection, transforms the individual experience into replicable regional experience, and provides scientific basis for implementation of educational policies, strategies and programs.

Evidence-based educational reform involves personnel from multiple agencies including academic researchers, think tank experts, primary and secondary school practitioners, government and school decision makers. Among them, teachers are the key force of evidence-based educational research and educational reform. Zhu and Zhu (2020) suggest that teachers' accumulation of practical knowledge and keen insights, the prerequisites of educational reform, provide theoretical support for the development of evidence-based research. Some scholars believe that evidence-based educational reform is not system reconstruction, but rather a process of improvement firmly rooted in school situations and teachers' practice (Pei et al., 2020).

(C) 2021 Insights Publisher. All rights reserved.

(c) (i) (-) Creative Commons Non Commercial CC BY-NC: This article is distributed under the terms of the Creative Commons Attribution-NonCommercial 4.0 License (http://www.creativecommons.org/licenses/by-nc/4.0/) which permits non-commercial use, reproduction and distribution of the work without further permission provided the original work is attributed by the Insights Publisher. 
China's teaching research system is a special organization in teachers' professional development, differing from other teacher bodies like teacher union. It not only organizes teachers' educational and teaching research, but also undertakes certain administrative functions. In this system, Chinese teachers receive vocational training compulsory for their teaching career, conduct research on teaching methods and strategies, and cultivate abilities to examine teaching from the perspective of learners (Darling-Hammond, 2000). It is an important link between classroom teaching and teaching reform. Based on the real teaching situations at school, teachers, under the guidance of this system, reflect regularly on teaching practice, discuss with their colleagues, and hold exchanges with higher-level teaching experts. In this way, teachers are self-motivated to gain a more comprehensive and profound understanding of teaching and their internal enthusiasm for learning and internal needs for professional progress are stimulated (Liu, 2021). Therefore, some scholars commented that teaching research in China is the result of teachers' professional competence and professional pursuit (Cheng, 2021).

With deepened basic educational reform in China, especially the curriculum reform, teaching research has also undergone a comprehensive transformation. The transition from experience to evidence has become a consensus in the development of teaching research reform. Teachers use standardized evidence and personal knowledge in implementing evidence-based teaching reform according to teaching objectives, students' practical situations and teaching conditions, aiming to improve teaching quality and teaching methods. In the issue of the journal, The Role of China's Teaching Research System in Promoting Evidence-based Reform in Education: A Case Study of Jiangsu Province by Zhou (2021) analyzed the patterns, characteristics and results of China's evidence-based reform in education and examined the roles of China's teaching research system in this reform, using a 15-year exploration of evidence-based educational reform from Jiangsu Province as a case study.

This paper indicates that China's teaching research system, a large and stable teaching research organization, has played a vital part in the follow-up evidence-based reform based on education quality survey, represented by Jiangsu Province. Its strengths in organization and execution and more importantly its application of accurate and scientific data contribute to the outcomes of educational reform. The transitions from experience to data and from mere knowledge impartment to comprehensive education mark outstanding achievements of China's evidence-based reform in education. 


\section{References}

Chen, J.M. (2021). Teaching research: treasure of China's education. Journal of East China Normal University (Educational Sciences), 39 (5):1-11. DOI: https://doi.org/10.16382/j.cnki.1000-5560.2021.05.001

Darling-Hammond, L. (2000). How teacher education matters. Journal of Teacher Education, 51(3):166-173. DOI: https://doi.org/10.1177/0022487100051003002

Liu, Y.X. (2021). Tracing Back to the Root: Teaching Research Originated from the Local Practice in China. Journal of East China Normal University (Educational Sciences), 39(5):85-98. DOI: https://doi.org/10.16382/j.cnki.1000-5560.2021.05.005

Pei, M., Jin, W., Li, X.Y., Liu, J., \& Liu, Q.R. (2020). Evidence-based Teacher Education Practice: Connotation, Values and Operational Mechanism. Teacher Education Research, (4):1-8. DOI: https://doi.org/10.13445/j.cnki.t.e.r.2020.04.001

Zhou, S. (2021). The role of China's educational research system in promoting evidencebased reform in education: A case study of Jiangsu province. Best Evidence in Chinese Education, 9(2):1227-1241. Doi: https://doi.org/10.15354/bece.21.or067

Zhu, X.D., \& Zhu, Z.Y. (2020, September 1). Building an evidence-based education system and promoting scientific and professional educational decision-making and practice. Guangming Daily, 09-01, P13. Retrieved from: https://epaper.gmw.cn/gmrb/html/2020- 09/01/nw.D110000gmrb 202009012 2$\underline{13 . h t m}$

Correspondence to: Alan C.K. Cheung, Ph.D. Department Chairperson \& Professor Department of Educational Administration and Policy

The Chinese University of Hong Kong Hong Kong 999077

China

E-mail: alancheung@cuhk.edu.hk

Conflict of Interests: None.

Doi: 10.15354/bece.21.co027 